\title{
Karikatur Covid-19 Dalam Media Daring Tempo dan Kompas: Kajian Semiotika
}

\author{
Arlyanti Dwi Putri, Muhammad Hasyim, Mardi Adi Armin \\ Fakultas Ilmu Budaya \\ Universitas Hasanuddin
}

\begin{abstract}
This study aims to describe the Covid-19 handling policies in the caricatures of @ tempodotco and @hariankompas and to determine the meaning depicted in the caricatures as well as public reactions to government policies. The data used are sourced from caricatures contained in the Instagram accounts @tempodotco and @ hariankompas regarding government policies in handling covid-19 published in March-December 2020. The data found are divided into 7 sub-themes, namely about elections, social assistance, new normal, work from home or studying from home, $P S B B$ or social distancing, government opinion, and the prohibition on going home. The author concludes that the results of this study are divided into two. The first is the depiction that appears about government policies and the reactions of the people that are depicted. The descriptions that emerge about government policies are divided into 4. (1) The determination of government policies is described as less strict on the implementation of health protocols. (2) Government policies that have been implemented are described as complying with the process but not providing solutions for the impacts that arise. (3) Opinions expressed by several government officials seem to underestimate COVID-19. (4) Misuse of social assistance for campaign purposes. The depiction emerges from the public's reaction to government policies. Divided into 3. (1) The community is described as not complying with government regulations properly. (2) Employees or students cannot perform their duties efficiently. (3) Human is depicted as a bird in a cage.
\end{abstract}

Keywords: Semiotic, Caricature, Covid-19, Pandemic

\section{Pendahuluan}

Karikatur merupakan media komunikasi antara karikaturis dan pembaca. Karikatur menurut Kamus Besar Bahasa Indonesia (KBBI) adalah gambar olok-olok yang mengandung pesan, sindiran, dan sebagainya. Karikatur adalah suatu penggambaran terhadap suatu objek dengan cara menonjolkan keunikannya tersendiri. Pesan dalam karikatur terbagi atas dua bentuk yaitu kode verbal dan kode nonverbal atau visual. Kode verbal adalah tulisan-tulisan yang terdapat dalam karikatur, sedangkan kode nonverbal adalah selain yang termasuk kode verbal. Kedua kode ini saling dihubungkan untuk dapat memecahkan pesan karikaturis.

Diaz (2012:7) mengatakan bahwa kesengajaan dalam membentuk sebuah pesan menggunakan bahasa simbol atau non verbal ini juga bukanlah tanpa maksud, penggunaan bentuk non verbal dalam karikatur lebih diarahkan kepada pengembangan interpretasi oleh pembaca secara kreatif, sebagai respon terhadap apa yang diungkapkan melalui karikatur tersebut. Dengan kata lain, meskipun dalam suatu karya karikatur terdapat ide dan pandangan-pandangan seorang 
karikaturis, tetapi melalui suatu proses interpretasi muatan makna yang terkandung di dalamnya akan dapat berkembang secara dinamis, sehingga dapat menjadi lebih kaya serta lebih dalam pemaknaannya.

Waluyanto (2000:128) juga mengatakan karikatur merupakan salah satu bentuk karya komunikasi visual yang efektif dalam penyampaian pesan kritik sosial. Dalam karikatur yang baik ada perpaduan unsur-unsur kecerdasan, ketajaman dan ketepatan berpikir kritis serta ekspresif dalam menanggapi fenomena kehidupan masyarakat, kritik sosial tersebut dikemas secara humoris. Jadi karikatur bukan hanya sebuah pesan berupa tulisan dan gambar, namun gambar ini diatur dengan sistem tertentu yang menjadikannya tajam, kritis dan humoris.

Karikatur di media massa tidak terlepas dari sifat keaktualan, karena di dalamnya mengikuti wacana publik yang berkembang saat itu. Konstruksi realitas tertentu yang disampaikan dalam bentuk visual merupakan wacana yang dimunculkan dalam karikatur. (Marulitua, 2015:80). Karikatur dalam sebuah media cenderung memiliki pesan tertentu yang ingin disampaikan oleh karikaturis. Pesan yang dapat ditangkap dalam suatu karikatur sangat banyak, sehingga diperlukan analisis yang mendalam untuk mencapai kesamaan presepsi. Karikatur dalam sebuah media merupakan ekspresi atau opini karikaturis terhadap wacana yang sedang berkembang. Pesan ini dibuat secara sengaja atau dengan konsep tertentu, namun memiliki makna yang ambigu sehingga pemaknaan yang dihasilkan bermacam-macam. Karikaturis menggiring pembacanya untuk mengkritisi suatu wacana.

Covid-19 merupakan salah satu tema karikatur media massa yang sering muncul sejak awal 2020. Virus yang ditemukan pada akhir tahun 2019 ini memberi dampak besar di seluruh Negara. Pembatasan mobilitas sebagai salah satu bentuk pencegahan berdampak pada ekonomi setiap Negara. Kasus penularan dan kematian yang ditimbulkan sangat banyak. Sudah banyak Negara yang melakukan vaksinisasi guna mencegah penyebaran virus. Namun hal ini masih belum menjadi jawaban atas permasalahan ini, bahkan varian covid-'19 yang baru banyak ditemukan. Penelitian karikatur dengan tema covid-19 menjadi menarik untuk diteliti. Banyaknya karikatur yang membahas tentang covid-19, membuat penulis membatasi data penelitian hanya karikatur yang berhubungan dengan kebijakan pemerintah.

Penelitian yang membahas tentang karikatur pandemi covid-19 tidak hanya ada di Indonesia tetapi juga di Negara-negara lain. Di Prancis misalnya Armin dan Amalia meneliti tentang karikatur yang muncul pada media online terkait tanggapan pemerintah Prancis terhadap pandemi Covid-19. Teori yang mereka gunakan adalah semiotika pierces, dengan data dalam media daring yang dibagi menjadi tiga bagian. Respons pemerintah terhadap pandemi, tanggapan masyarakat, optimisme dan pesimisme masyarakat, sindiran kepada pemerintah Cina.

Alkhresheh (2020) meneliti tentang karikatur yang terdapat di Pakistan dan Britain. Koran Dawn sebagai representasi Pakistan dan The Economist dari Britain. Karikatur yang terdapat dalam Dawn membahas tentang masalah domestik sistem kesehatan, dan The Economist membahas tentang kondisi Brasil yang genting dan ketidakefisienan pemerintah dalam menangani penyebaran covid-19. Perbedaan kedua penelitian ini dengan penulis terletak pada data dan teorinya. Untuk penelitian Armin dan Amalia teori yang digunakan sama-sama Pierces, tetapi data yang digunakan adalah karikatur media daring di Indonesia. Alkhersheh menggunakan dua teori yaitu analisis wacana kritis dan semiotika Barthes.

Berdasarkan penjelasan di atas maka penulis menarik beberapa alasan yang menjadi urgensitas penelitian. Pertama, karikatur merupakan opini atau pesan karikaturis yang terselip dengan fakta. Karikaturis tidak sekedar menyampaikan opininya secara sembarangan tetapi ada fakta di dalamnya, sehingga maknanya cukup tajam. Kedua, dikarenakan pemaknaannya yang 
ambigu maka respon yang dimunculkan dapat berbeda-beda. Karikaturis biasanya tidak memperlihatkan secara jelas makna karikaturnya. Pembaca diajak untuk mengkritisi masalah yang terjadi. Ketiga, karikatur yang muncul mengikuti tren atau masalah yang diperbincangkan. Adapun data yang diambil adalah karikatur covid-19 dalam akun instagram @ tempodotco yang terbit pada bulan Maret - Desember tahun 2020. Diharapkan analisis data dengan menggunakan teori semiotika dapat menjawab pertanyaan berikut. (1) Bagaimana penggambaran kebijakan penanganan covid-19 dalam karikatur @ tempodotco dan @ harian kompas ? dan (2) Bagaimana makna yang tergambarkan dalam karikatur serta reaksi masyarakat terhadap kebijakan pemerintah?

\section{A. Kartun dan Karikatur}

Cartoons are portrayals in the form of paintings or caricatures about people, ideas, or situations designed to influence people/ society (Robingah, 2020:1). Kartun adalah potret dalam bentuk gambar atau karikatur tentang orang, ide, atau situasi yang dibuat dengan tujuan mempengaruhi orang atau masyarakat. Karikatur menurut Pramono (dalam Sobur, :138) adalah bagian dari kartun opini, tetapi kemudian menjadi salah kaprah. Karikatur yang sudah diberi pesan, kritik, dan sebagainya berarti telah menjadi kartun opini.

Karikatur adalah suatu penggambaran terhadap suatu objek dengan cara menonjolkan keunikannya tersendiri. Richmond (2011:2-5) menjelaskan bahwa sebuah karikatur yang bagus adalah yang memiliki tiga unsur atau elemen yaitu recognizability, exaggeration, statement. Recognizability maksudnya adalah sebuah karikatur harus memiliki keunikan tersendiri yang langsung mengingatkan akan subjek gambarannya meskipun gambar tersebut sangat berlebihan. Jika gambar tersebut tidak dapat menunjukkan subjeknya, maka itu bukan karikatur. Karikatur juga harus gambar yang exaggeration atau berlebih-lebihan. Misalnya gambar yang sengaja dibuat bervolume besar atau gambar yang dilebih-lebihkan untuk bagian tertentu yang menjadi suatu keunikan bagi karikaturisnya. Statement yang dimaksud bukanlah suatu pernyataan tetapi personality atau sifat subjek gambarnya yang langsung menegaskan subjeknya.

Karikatur memperlihatkan bagaimana karikaturis memandang subjeknya dengan gambarnya. Karikatur harus bisa menunjukkan subjeknya dengan menunjukkan keunikan yang ditemukan oleh karikaturis, baik dari segi sifat maupun fisiknya dengan cara penggambaran yang dilebih-lebihkan. Selama pandemi Covid - 19 banyak bermunculan tentang karikatur Covid - 19 . Karikatur-karikatur ini merupakan sindiran yang mengandung lelucon tentang keresahan masalah Covid-19, dan hal ini tidak hanya terjadi di Indonesia. Di Prancis misalnya Mardi dan Amalia dalam jurnalnya Semiotika Karikatur Pandemi Covid-19 Melalui Media Daring (On Line) Di Perancis (2020: 284-291) menemukan bahwa karikatur media daring di Prancis dapat dibagi menjadi beberapa bagian, yaitu respons pemerintah terhadap pandemi, tanggapan Masyarakat, optimisme dan pesimisme masyarakat, sindiran kepada pemerintah Cina. Karikatur di Pakistan membahas tentang masalah domestik sistem kesehatan dan Britain membahas tentang kondisi Brasil yang genting dan ketidakefisienan pemerintah dalam menangani penyebaran covid-19.

Di Indonesia karikatur Covid-19 juga banyak bermunculan. Misalnya karikatur Covid di beberapa media Indonesia seperti tempo, kompas, republika, inilah.com, satuharapan.com, jabarnews.com, dan postingan-postingan di media sosial. Himpunan Psikolog Indonesia (HPI) juga membuat karikatur untuk mengedukasi anak yang dapat dilihat dan didownload melalui laman resminya. 


\section{B. Semiotika}

Secara sederhana, semiotika adalah ilmu yang memsiswai tentang tanda. Semiotika merupakan ilmu yang memsiswai proses penandaan dan hasil penandaan itu sendiri. Namun, 'tanda' ini lah yang sulit dijelaskan. Tanda adalah segala sesuatu yang bisa dimaknakan. Secara Terminologis, semiotika dapat didefinisikan sebagai ilmu yang memsiswai sederetan luas objekobjek, peristiwa-peristiwa, seluruh kebudayaan sebagai tanda (Eco dalam Sobur, 2018:5). Van Zoest (dalam Sobur, 2018:5-6) mengartikan semiotika sebagai "ilmu tanda (sign) dan segala yang berhubungan dengannya: cara berfungsinya, hubungannya dengan kata lain, pengirimannya, dan penerimaannya oleh mereka yang mempergunakannya.

Menurut Ferdinand de Saussure, penanda dan petanda merupakan komponen tanda (de Saussure dalam Barthes, 2012:27). Tanda dalam semiotika Roland Barthes (2011:158) adalah kesatuan asosiatif dari penanda dan petanda. Tanda merupakan hasil dari semiologis. Petanda merupakan representasi mental dari benda. Petanda hanya dapat dijelaskan melalui proses penandaan. Petanda ialah sesuatu yang dimaksudkan oleh orang yang menggunakan tanda tertentu. Menurut Saussure dalam Roland Barthes (2011:159) petanda adalah konsep, sedangkan penanda adalah citra akustik (yang bersifat mental) dan hubungan antara konsep dan citra adalah tanda.

Saussure (dalam Christomy dan Yuwono, 2004:90) menjelaskan bahwa 'tanda' sebagai kesatuan yang tak dapat dipisahkan dari dua bidang-seperti halnya selembar kertas-yaitu bidang penanda (signifier) untuk menjelaskan 'bentuk' atau 'ekspresi' ; dan bidang petanda (signified) untuk menjelaskan 'konsep' atau 'makna'.

Satu petanda bisa memiliki beberapa penanda. Contohnya pada petanda OK di Indonesia, petanda tersebut baru bisa ditentukan tandanya jika penandanya jelas. Penanda ada untuk memiskinkan makna petanda sehingga terbentuklah tanda.

Tanda bagi Pierce (dalam Zoest, 1993 :10) hanya berarti tanda apabila ia berfungsi sebagai tanda. Fungsi essensial tanda bagi Pierce dijelaskan Zoest (1993 : 11) adalah membuat sesuatu efisien, baik dalam komunikasi kita kepada orang lain maupun dalam pemikiran dan pemahaman kita tentang dunia. Menurut Pierce, semua itu kita lakukan dengan menetapkan apa yang kita percayai. Kita mempercayai segala sesuatu, tapi seringkali kita sangat tidak menyadari hal itu. Dengan bantuan perangkat yang disajikan oleh semiotika, kita lebih menyadari apa yang kita dan orang lain percayai, tentang apa yang sebagai ‘kebiasaan dalam kepercayaan' mendasari pemikiran dan perilaku manusia.

Peirce (dalam Zoest, 1993:10) menjelaskan bahwa tugas seorang ahli logika adalah memahami bagaimana manusia bernalar (penalaran itu sendiri dapat diserahkan pada ilmu pasti). Untuk dapat mencapainya, logika jangan sampai membatasi bidang perhatiannya tetapi seakanakan harus melewati semua batas yang ada. Menurut Peirce (dalam Zoest, 1993:10) logika mengakar pada sesuatu yang menyangkut masyarakat. Sambil menyusun suatu teori mengenai bernalar, Pierce sampai pada keyakinan bahwa manusia berpikir dalam tanda. Maka demikianlah Peirce menciptakan ilmu tanda. Baginya, 'semiotika' sinonim dengan 'logika'. Secara harfiah ia mengatakan:" kita hanya berpikir dalam tanda."

Telah dikatakan sebelumnya bawa tanda dapat dikatakan tanda apabila memenuhi fungsi esensial tanda, yaitu mengefisienkan komunikasi atau pemahaman dan pemikiran kita tentang dunia. Ciri-ciri tanda menurut Pierce (dalam Zoest, 1993: 11-16) dapat dijelaskan sebagai berikut. a) Tanda harus dapat diamati agar dapat berfungsi sebagai tanda.

Sifat dapat diamati ini ada batasnya tetapi batasannya tidak dapat dirumuskan dengan tepat. Sebuah tanda harus 'bisa-ditangkap' atau 'diamati' agar dapat berfungsi sebagai tanda, tetapi proses pengamatan atau penangkapan itu tidaklah penting 
b) Tanda menunjukkan pada sesuatu yang lain sesuatu yang tidak hadir.

Tanda sebagai semacam wakil untuk sesuatu yang tidak hadir tetapi merupakan bagian dari kenyataan. Ada tiga unsur yang menentukan tanda: Tanda yang dapat ditangkap itu sendiri, yang ditunjuknya, dan tanda baru dalam bentuk si penerima tanda. Antara tanda dan yang ditunjuknya terdapat relasi: tanda mempunyai sifat representatif. Tanda dan representasi mengarahkan pada interpretasi; tanda mempunyai sifat representatif. Dengan perkataan lain, representasi dan interpretasi merupakan ciri khas tanda.

Istilah representasi dan interpretasi menjadi konflik. Ini karena kata representasi dan interpretasi menunjukkan tindakan dan hasil tindakan tersebut. Sehingga istilah tersebut diubah, kata representasi diubah menjadi denotatum dan kata interprestasi diubah menjadi interpretan.

c) Sesuatu hanya dapat merupakan tanda atas dasar satu dan lain.

Peirce menyebutnya ground (dasar, latar) dari tanda. Ground tidak harus selalu merupakan suatu keseluruhan dari perjanjian-perjanjian sistematis yang dapat dilukiskan ( kode), tetapi bisa juga sesuatu yang tidak dapat dilukiskan seperti kebiasaan nonbahasa. Tanda-tanda seringkali berfungsi tanpa kode. Kode-kode meski tidak selalu, sering merupakan ground dari suatu tanda. karena itu, kalau yang kita maksudkan adalah apa yang mendasari tanda sehingga menjadi tanda, maka perbincangan bukanlah mengenai kode tetapi, secara umum mengenai ground. Ground, kode ataupun tidak, tentunya hanya ada karena tampil dalam kesadaran si pemakai tanda. Tidak ada ground yang berlaku umum atau abadi, jadi juga tak ada tanda yang umum atau abadi. Tanda tergantung pada keterbatasan, pembatasan dari segala sesuatu yang terjadi di dalam dunia kita. Dari penjelasan di atas, dapat dilihat bahwa ada tiga dimensi yang membentuk tanda, yaitu Representamen (R), Objek (O), dan Interpretant (I). Hubungan ketiga dimensi ini membentuk sebuah segitiga yang dinamakan segitiga tanda (triadik).

Interpretan (I)

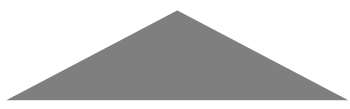

\section{Representamen (R) Objek (O)}

Cristomy (2004:117) menjelaskan Representamen (R) bentuk yang diterima oleh tanda atau mempunyai fungsi sebagai tanda, Objek (O) suatu yang terwakili dari penanda yang berhubungan dengan landasan, dan Interpretant (I) tanda yang terdapat di angan-angan setiap orang mengenai objek yang diarahkan suatu tanda.

Istilah lain yang perlu dipahami dalam teori semiotika Peirce adalah objek atau Zoest sendiri menyebutnya sebagai denotatum. Pierce (dalam Zoest, 1993 :23) menjelaskan denotatum tidak harus sesuatu yang konkrit, dapat juga abstrak. Denotasi dari kata 'atau' yang disebut di atas adalah semacam itu. Denotatum dapat berupa sesuatu yang ada; sesuatu yang kita anggap pernah ada atau akan ada; mungkin dapat dibayangkan, tetapi mungkin juga tidak dapat dibayangkan. Semua yang dapat terpikirkan dan yang tidak dapat terpikirkan dapat merupakan denotatum dari suatu benda. Jika digambarkan dalam segitiga semiotika, maka letaknya bisa dilihat pada gambar berikut.

Interpretant

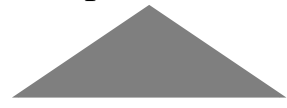

Representamen

Objek

Ikon

Indeks 
Simbol

(Christomy, 2004:127)

Pierce membedakan tiga macam tanda menurut sifat penghubungan tanda dan denotatum.

1. Ikon

Ikon menurut Sobur (2018:98), adalah sesuatu yang melaksanakan fungsi sebagai penanda yang serupa dengan bentuk objeknya (lihat pada gambar atau lukisan). Sehingga ikon memiliki ciri khusus dapat dilihat. Menurut Peirce (dalam Zoest, 1994:24) tanda ikonis adalah tanda yang ada sedemikian rupa sebagai kemungkinan, tanpa tergantung pada adanya sebuah denotatum, tapi dapat dikaitkan dengannya atas dasar suatu persamaan yang secara potensial dimilikinya. Ini menandakan bahwa segala sesuatu merupakan ikon, karena semua yang ada dalam kenyataan dapat dikaitkan dengan sesuatu yang lain. Ikon dalam arti sempit hanya ada menurut cara eksistensi dari apa yang mungkin.

Penjelasan di atas menunjukkan bahwa ikon adalah sesuatu yang dapat dilihat, ia mirip dengan bentuk objeknya, ikon di dalam kenyataannya tidak muncul dalam bentuk murni. Ikon baru berfungsi sebagai sebuah tanda apabila dikaitkan dengan sesuatu yang berpotensi menjadi tanda.

2. Indeks

Sobur (2018:98) menjelaskan indeks sebagai sesuatu yang melaksanakan fungsi sebagai penanda yang mengisyaratkan petandanya. Zoest (1993 :24-25) juga menjelaskan indeks adalah sebuah tanda yang dalam hal corak tandanya tergantung dari adanya sebuah denotatum. Dalam hal ini, hubungan antara tanda dan denotatum adalah bersebelahan nya. contohnya tidak ada asap tanpa api, asap dapat dianggap sebagai tanda untuk api. Tanda indeks memiliki hubungan timbal-balik atau sebab-akibat, keduanya saling mempengaruhi dan harus mempunyai persamaan 'sifat'.

3. Lambang (Simbol)

Simbol (lambang) menurut Zoest (1993:27) adalah tanda yang hubungan antara tanda dan denotatumnya ditentukan oleh suatu peraturan yang berlaku umum. Sobur (2018:98) menjelaskan sesuatu yang melaksanakan fungsi sebagai penanda yang oleh kaidah secara konvensi telah lazim digunakan dalam masyarakat. Jadi, tanda simbol berhubungan dengan suatu peraturan atau persamaan pengetahuan dari sekelompok orang.

Secara sederhana perbedaan ketiganya bisa dilihat pada tabel berikut:

\begin{tabular}{|l|l|l|l|}
\hline Tanda & Ikon & Indeks & Simbol \\
\hline $\begin{array}{l}\text { Ditandai } \\
\text { dengan: }\end{array}$ & $\begin{array}{l}\text { Persamaan } \\
\text { (kesamaan } \\
\text { ) }\end{array}$ & $\begin{array}{l}\text { Hubunga } \\
\text { n sebab- } \\
\text { akibat }\end{array}$ & $\begin{array}{l}\text { Konve } \\
\text { nsi }\end{array}$ \\
\hline Contoh: & $\begin{array}{l}\text { Gambar- } \\
\text { gambar } \\
\text { dan } \\
\text { patung- } \\
\text { patung } \\
\text { Tokoh } \\
\text { besar Foto } \\
\text { Reagan }\end{array}$ & $\begin{array}{l}\text { Asap/api } \\
\text { Gejala/Pe } \\
\text { nyakit }\end{array}$ & $\begin{array}{l}\text { Kata- } \\
\text { kata } \\
\text { isyarat }\end{array}$ \\
\hline Proses: & $\begin{array}{l}\text { Dapat } \\
\text { dilihat }\end{array}$ & $\begin{array}{l}\text { Dapat } \\
\text { diperkira } \\
\text { kan }\end{array}$ & $\begin{array}{l}\text { Harus } \\
\text { disiswa } \\
\text { i }\end{array}$ \\
\hline
\end{tabular}

(Sobur, 2017: 34) 
Tabel diatas menunjukkan bahwa ikon adalah suatu tanda yang memiliki persamaan atau kesamaan dengan objeknya. Ikon ini tidak bergantung pada denotatumnya, tetapi potensial tanda yang muncul dari eksistensinya. Prosesnya dapat dilihat. Contoh dari indeks adalah Gambargambar dan patung-patung Tokoh besar Foto Reagan. Indeks ditandai dengan adanya hubungan sebab- akibat. Contohnya asap menunjukkan adanya api, proses ini walaupun tidak dapat dilihat, tetapi dapat diperkirakan. Simbol ditandai dengan konvensi, contohnya berupa kata-kata isyarat, dan dalam prosesnya harus disiswai.

Peirce (dalam Sobur, 2018:98-99, dalam Santosa 1993:11-12) lebih jauh menjelaskan bahwa tipetipe tanda seperti ikon, indeks, dan simbol, memiliki nuansa-nuansa yang dapat dibedakan.

Perbedaan antara ikon, indeks, dan simbol secara lebih jelas dapat dilihat pada contoh dengan objek "kucing" berikut ini:

\begin{tabular}{|ll|ll|ll|}
\hline \multicolumn{2}{|c|}{ Ikonis } & \multicolumn{2}{|c|}{ Indeksikal } & & \multicolumn{2}{c|}{ Simbolis } \\
\hline a. & Lukisan kucing & a. & Suara Kucing & a. & Diucapkannya kata kucing \\
b. & Gambar kucing & b. & Suara langkah- & b. & Makna gambar kucing \\
c. & Patung kucing & langkah kucing & c. & Makna suara kucing \\
d. & Foto kucing & c. & Bau kucing & d. & Makna bau kucing \\
e. & Sketsa Kucing & d. & Gerak kucing & e. & Makna gerak kucing \\
\hline
\end{tabular}

(Sobur, 2018:99)

Lukisan, gambar, patung, foto atau sketsa kucing yang mengacu pada objek kucing adalah ikonis. Contoh ikonis ini menunjukkan ada kesamaan atau persamaannya tetapi yang menjadi denotatumnya tidaklah penting. Jika kucing bersuara atau terdengar suara langkah kakinya, ada bau kucing bahkan, gerak kucing menunjukkan keberadaan kucing, menunjukkan hubungan sebab-akibat atau (indeksikal). Suatu tanda yang diucap, atau makna dari: gambar, bau, lukisan, gerak, adalah simbolis

\section{Metode}

Penelitian ini merupakan penelitian kualitatif dengan menggunakan teori semiotika. Penelitian kualitatif menurut Sugiyono (2017:14) metode penelitian kualitaitf sering disebut sebagai metode penelitian naturalistik karena penelitiannya dilakukan pada kondisi yang alamiah. (natural setting); disebut juga sebagai metode etnographi, karena pada awalnya metode ini lebih banyak digunakan untuk penelitian bidang antropologi budaya; disebut sebagai metode kualitatif, karena data yang terkumpul dan analisisnya lebih bersifat kualitatif. Teori yang digunakan dalam penelitian ini adalah teori semiotika Peirce yaitu ikon, indeks, simbol. Hasil penelitian nantinya akan dijelaskan secara deskriptif dan bukan angka.

Sumber data adalah karikatur yang terdapat dalam instagram resmi media kompas (@ hariankompas) dan tempo (@tempodotco) di tahun 2020. Data dibatasi pada tahun 2020 karena pada tahun itu karikatur tentang covid-19 sangat banyak. Total karikatur covid-19 pada tahun 2020 ada sekitar 49.

Data dalam penelitian ini berupa karikatur yang terdapat dalam @tempodotco dan @ hariankompas bertemakan covid-19. Karikatur yang dipilih adalah karikatur yang terbit pada tahun 2020. Media kompas memiliki 31 karikatur dan tempo 18 karikatur. Karikatur ini dibatasi hanya yang membahas tentang kebijakan pemerintah terhadap penanggulangan covid-19, sehingga total karikatur yang akan diteliti adalah 19. Komentar yang berhubungan dengan postingan tersebut pada kolom komentar akan disimpan untuk dijadikan acuan dalam menginterpretasi karikatur tersebut. 
Metode yang digunakan untuk mengumpulkan data adalah metode observasi dan dokumentasi. Penulis mengamati calon data yang ada pada @tempodotco dan @hariankompas. Data tersebut kemudian didokumentasikan dengan cara menscreenshot atau rekam layar karikatur dan dipindahkan ke dokumen. Data yang akan dianalisis berjumlah 19 karikatur. Data ini dikumpulkan berdasarkan tema karikatur covid-19 yang membahas tentang kebijakan pemerintah. Dari kebijakan tersebut juga dilihat komentar yang sesuai dengan karikatur. Jika tidak ada, maka karikatur tersebut tidak digunakan.

Teknik analisis data yang digunakan oleh penulis, dibagi ke dalam beberapa tahap, yaitu: 1. Mengidentifikasi karikatur yang membahas tentang Covid-19 pada akun instagram @ tempodotco dan @ hariankompas di tahun 2020.

2. Karikatur yang ditemukan kemudian disimpan dan diseleksi kembali. Karikatur yang membahas tentang kebijakan pemerintah terhadap penanggulangan covid-19 akan diperiksa, dan dibagikan sesuai sub-tema yamg ditemukan.

3. Data yang ditemukan kemudian akan dibagi berdasarkan jenis kodenya. Kode verbal akan dianalisis menggunakan teori dikotomo atau skema diadik. Kode non verbal atau visual akan dianalisis menggunakan teori triadik atau ikon, indeks dan simbol. Analisis ini dilakukan untuk menemukan jawaban rumusan masalah pertama dan kedua.

Hasil analisis diharapkan dapat memperlihatkan makna yang muncul dari karikatur covid-19 dalam @ tempodotco dan@hariankompas.

\section{Hasil dan Pembahasan}

Penulis menemukan bahwa kebijakan pemerintah dalam karikatur covid-19 dapat dibagi menjadi 7 bagian, yaitu pelaksanaan pilkada, bantuan sosial, larangan mudik, WFH/belajar di rumah, PSBB/ jaga jarak, opini pemerintah dan masalah ekonomi atau kesehatan. Data karikatur ini akan dibagi menjadi 2, yaitu data dalam bentuk kode verbal maupun kode visual. Kode verbal penelitian ini adalah tulisan-tulisan yang terdapat dalam karikatur, baik dalam bentuk ujaran atau teks dalam gambar. Kode visual adalah gambar yang terdapat dalam karikatur. Kode-kode ini kemudian akan dianalisis dengan teori yang berbeda, penanda - petanda, dan ikon, indeks, simbol.

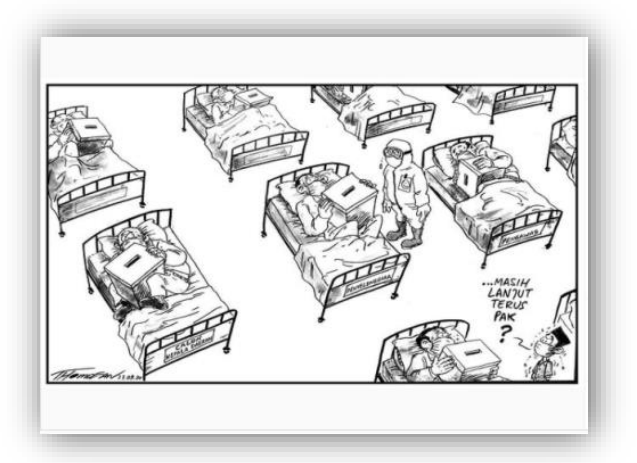

\section{Gambar 1 'Masih Lanjut Terus Pak?'}

Gambar 1 menggambarkan beberapa orang yang sedang terbaring dengan menggunakan masker. Orang-orang ini memegang kotak pemilu. Pada tempat tidurnya terdapat tulisan calon kepala daerah, penyelenggara, pengawas. Seorang mengenakan APD (Alat Perlindungan Diri) lengkap dan terlihat prihatin, tetapi di luar APDnya terdapat emoji tersenyum. Di gambar bagian bawah terlihat seorang pria yang memakai kemeja pendek, kopiah, dan masker. Pria ini terlihat ketakutan sambil bertanya '....masih lanjut terus pak?'. 
Karikatur ini menggambarkan situasi pandemi menjelang pilkada serentak tanggal 9 Desember 2020. Menjelang pelaksanaan pilkada, peningkatan kasus covid-19 masih terjadi. Bahkan pada tanggal 4 Oktober 2020, 3 bakal calon kepala daerah meninggal karena terinfeksi virus covid-19. Ketiganya Muharram (calon petahana Bupati Berau), Adi Darma (calon Walikota Bontang), dan Ibnu Saleh (calon petahana bupati Bangka Tengah) (Danang, 2020). Bawaslu sempat mengajukan penundaan pilkada namun hal ini ditentang oleh Presiden. Padahal diberitakan dalam metrotvnews (2020) pada tanggal 10 September 2020, ketua KPU menyampaikan salah satu anggota Komisaris KPU Evi Norida Ginting positif covid-19. Tidak lama setelahnya Ketua KPU dan Pramono Ubaid juga dinyatakan positif covid-19. Peningkatan kasus terutamanya diantara penyelenggara pemilu terus terjadi, namun pilkada tetap dilaksanakan.

A. Kode Verbal

a) Teks Karikatur

\begin{tabular}{|l|l|l|l|}
\hline \multicolumn{1}{|c|}{$\begin{array}{c}\text { Ujaran } \\
\text { Karikaturial }\end{array}$} & \multicolumn{3}{|c|}{ Teks dalam Gambar } \\
\hline $\begin{array}{l}\text {...Masih lanjut } \\
\text { terus Pak? }\end{array}$ & $\begin{array}{l}\text { Calon kepala } \\
\text { daerah }\end{array}$ & Penyelenggara & Pengawas \\
\hline
\end{tabular}

\section{b) Signifikasi Teks Karikatur}

Penanda ...masih lanjut terus Pak? merupakan pertanyaan yang meragukan kesuksesan pelaksanaan pilkada 2020. Menjelang pelaksanaan pilkada, kasus positif covid-19 di Indonesia semakin bertambah, pelanggaran protokol kesehatan juga sering terjadi. Pertanyaan ini meragukan sekaligus mengkritik pemerintah yang masih tetap bersikeras melaksanakan pilkada. Keraguan ini terlihat dari tiga tanda titik yang muncul di awal kalimat. Tanda tersebut menunjukkan bahwa pembicara terdiam sejenak sebelum bertanya. Selain itu, tanda tanya yang muncul di akhir kalimat merupakan bentuk pertanyaan dari ujaran ini. Kata masih dalam ujaran memperlihatkan kritikan terhadap pemerintah. Dalam situasi peningkatan kasus akibat pelaksanaan pilkada, perlukah pilkada dilanjutkan?

\begin{tabular}{|c|c|}
\hline Penanda & Petanda \\
\hline ...Masih lanjut terus Pak? & Meragukan pelaksanaan pilkada \\
\hline
\end{tabular}

Penanda calon kepala daerah, penyelenggara dan pengawas merupakan petanda yang menunjukkan bahwa kasus ini berhubungan dengan pilkada. Ditambah dengan adanya kotak pemilu di tangan masing-masing pasien, menjadi bukti yang kuat bahwa mereka adalah pasien dari klaster pelaksanaan pilkada.

B. Kode Visual

1. Ikon

$$
\text { Ikon } \begin{aligned}
& \text { TenagaKesehatan } \\
& \text { Calon Kepala Daerah } \\
& \text { Pelaksana } \\
& \text { Penyelenggara } \\
& \text { Kepala Desa, Lurah atau } \\
& \text { Ketua RT/RW }
\end{aligned}
$$

Ikon memiliki persamaan antara tanda dan objek yang dimaksudkannya.

1) Seseorang dengan pakaian APD lengkap merupakan ikon tenaga kesehatan yang menangani kasus covid-19. Biasanya APD hanya dikenakan oleh orang-orang yang menangani pasien penyakit menular atau covid- 19 .

2) Calon kepala daerah merupakan ikon dari pria dengan tulisan 'calon kepala daerah' di tempat tidurnya. 
3) Penyelenggara pilkada merupakan ikon dari pria dengan tulisan 'penyelenggara' di tempat tidurnya.

4) Ikon pelaksana pilkada terlihat dari pria dengan tulisan 'pelaksana' di tempat tidurnya.

5) Seorang pria yang mengenakan kemeja pendek, masker dan kopiah menunjukkan ikon dari kepala desa, lurah atau ketua RT/RW yang merupakan bagian dari penyelenggara pilkada di daerah masing-masing.

2. Indeks

Secara sederhana indeks dapat dijelaskan sebagai hubungan sebab-akibat atau 'kesamaan sifat'.

Indeks $<_{\text {Tempat Tidur/orang sakit }}^{\text {Kotak Pemilu }}$

Indeks yang terlihat dari karikatur ini adalah hubungan antara penyelenggaraan pilkada yang dikhawatirkan menjadi penyebab peningkatkan kasus covid-19.

1) Orang-orang memakai masker dan memegang kotak pemilu sambil terbaring sakit. Adanya kotak pemilu ini menunjukkan bahwa mereka berhubungan dengan pilkada.

2) Gambar tempat tidur yang banyak dengan orang-orang yang terbaring sakit menggambarkan ruangan tersebut berada di rumah sakit. Peningkatan kasus juga terlihat dari banyaknya orangorang yang terbaring di tempat tidur.

\section{Simbol}

Simbol adalah tanda yang muncul karena kesepakatan bersama.

Simbol $\begin{aligned} & \text { Masker } \\ & \text { Emoji Tersenyum/ Ekspresi } \\ & \text { Khawatir } \\ & \text { Ekspresi Ketakutan }\end{aligned}$

Simbol data gambar 1 adalah ekspresi ketakutan tenaga kesehatan tetapi emoji tersenyum terpasang di APD yang dikenakannya. Tenaga kesehatan ini terlihat khawatir di luar namun sesungguhnya merasa bahagia di dalam. Penambahan kasus covid-19 menjelang pelaksanaan pilkada membuat tenaga kesehatan gerah dengan kebijakan pemerintah yang tidak konsisten dengan aturan kesehatan. Tenaga kesehatan digambarkan senang terhadap peningkatan kasus positif pejabat akibat ulah mereka sendiri.

Masker yang digunakan oleh pasien dan orang-orang di lokasi menunjukkan bahwa penyakit yang di derita adalah penyakit menular, yaitu covid-19. Selain itu, di gambar bagian bawah terlihat seorang pria yang memakai kemeja pendek, kopiah, dan masker. Pria ini menjadi wakil masyarakat yang takut terhadap pelaksanaan pilkada. Hal ini terlihat dari pertanyaannya '....masih lanjut terus pak?'. Pria ini mempertanyakan kelanjutan pilkada di saat peningkatan kasus covid-19 masih terus terjadi.

Berdasarkan analisis kode visual dan kode verbal di atas terlihat bagaimana pemerintah dalam kebijakan pelaksanaan pilkada membuat masyarakat khawatir. Kebijakan pemerintah tentang pelaksanaan pilkada digambarkan justru menyebabkan terjadinya peningkatan kasus yang memunculkan reaksi ketakutan dalam masyarakat. Tenaga kesehatan (nakes) yang berada di garda depan digambarkan bahagia melihat penambahan kasus positif oleh pejabat. Mereka senantiasa mengingatkan tentang protokol kesehatan namun, pemerintah sendiri yang melonggarkan aturan tersebut. 


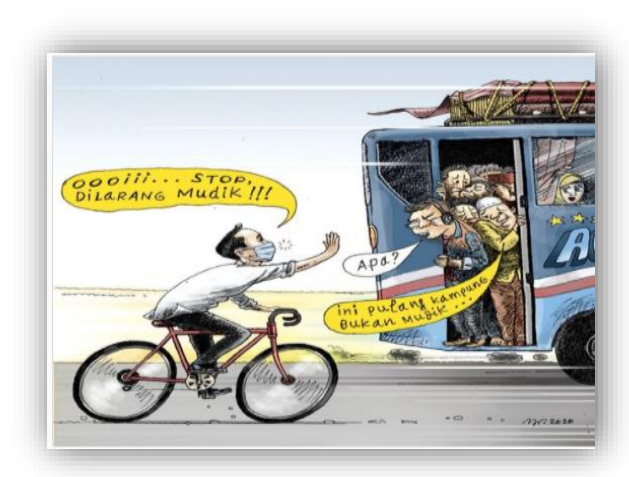

\section{Gambar 2 Dilarang Mudik Tapi Boleh Pulang Kampung}

Karikatur Dilarang Mudik Tapi Boleh Pulang Kampung berhubungan dengan pernyataan fenomenal Presiden Jokowi bahwa mudik dan pulang kampung itu berbeda. Jokowi (dalam Najwa Shihab, 2020) mengatakan kalau itu bukan mudik. Itu namanya pulang kampung. Memang bekerja di Jabodetabek, di sini sudah tidak ada pekerjaan lalu mereka pulang karena anak istrinya memang ada di kampung. Pernyataan inilah yang menyebabkan kebingungan antara mudik dan pulang kampung. Mentri perhubungan, Budi Karya Sumadi (dalam Ramli, 2020) mengatakan bahwa mudik dan pulang kampung itu sama. Memang dalam KBBI pun mudik adalah pulang ke kampung halaman. Namun tetap saja pernyataan Presiden Jokowi terlanjur menimbulkan kebingungan.

A. Kode Verbal

a) Teks Karikatur

\begin{tabular}{|l|}
\hline \multicolumn{1}{|c|}{ Ujaran Karikaturial } \\
\hline Oooiii... Stop, Dilarang Mudik !!! \\
\hline Apa? \\
\hline Ini pulang kampung, bukan mudik \\
\hline
\end{tabular}

b) Signifikasi Teks Karikatur

\begin{tabular}{|c|c|}
\hline Penanda & Petanda \\
\hline Oooiii... Stop, Dilarang Mudik !!! & Peringatan untuk tidak mudik \\
\hline
\end{tabular}

Oooiii... Stop, Dilarang Mudik !!! adalah penanda yang berisi peringatan atau larangan untuk tidak mudik. Penanda ini mewakili perintah larangan dari menteri perhubungan untuk tidak mudik pada tanggal 24 April - 31 Mei 2020. Oooiii... adalah kata seru yang digunakan untuk mencari perhatian pemudik. Stop, Dilarang Mudik !!! mengacu kepada peraturan pemerintah yang melarang mudik sebelum dan sesudah perayaan ied. UK.1 ini merupakan peringatan oleh Presiden Jokowi kepada pemudik untuk tidak mudik.

\begin{tabular}{|l|c|}
\hline \multicolumn{1}{|c|}{ Penanda } & Petanda \\
\hline Apa? & Pura-pura tidak tahu \\
\hline
\end{tabular}

Penanda Apa? menunjukkan bahwa pemudik ini tidak mendengarkan perkataan Presiden Jokowi. Kata Apa? Memperlihatkan dia tidak mendengar dan ingin agar perkataan tersebut di ulang. Headphone yang ada ditelinga mempertegas bahwa alasan pemudik ini tidak mendengar karena ada yang menutup telinganya. Pertanyaan ini mewakili sebagian masyarakat yang tidak mendengar perintah larangan tersebut atau bahkan berpura-pura tidak tahu. 


\begin{tabular}{|c|c|}
\hline Penanda & Petanda \\
\hline Ini pulang kampung, bukan mudik & Pembelaan diri \\
\hline
\end{tabular}

Ini pulang kampung, bukan mudik merupakan pembelaan dari pemudik. Mengacu pada pernyataan Presiden Jokowi dalam Mata Najwa, mereka membedakan makna pulang kampung dan mudik. Mereka tidak melanggar aturan pemerintah untuk mudik namun mereka hanya pulang kampung. Kedua kata tersebut memang memiliki makna yang mirip.

B. Kode Visual

1. Ikon

Ikon memiliki persamaan antara tanda dan objek yang dimaksudkannya.

Ikon $<$ Pokowi

1) Jokowi digambarkan dengan pria berbaju putih yang mengejar bus dengan sepeda. Presiden Jokowi terkenal dengan gaya berpakaiannya yang sederhana, terutamanya kemeja panjang berwarna putih. Beliau juga dikenal suka dengan sepeda.

2) Pemudik digambarkan dengan orang-orang di dalam bus yang melaju kencang. Di atas bus ada koper yang diikat dengan tali. Bus yang seperti itu biasanya dinaiki oleh pemudik.

2. Indeks

Secara sederhana indeks dapat dijelaskan sebagai hubungan sebab-akibat atau 'kesamaan sifat'. Indeks $<$ Sepeda

1) Sepeda merupakan ciri khas presiden Jokowi. Jokowi terkenal menyukai sepesa dan beberapa kali diberitakan menghadiahkan sepeda. Sepeda memiliki hubungan dengan presiden Jokowi.

2) Headphone memiliki hubungan indeksikal dengan UK. 2. Pemudik tidak dapat mendengar dengan baik pertanyaan Jokowi karena headphone di telinganya.

3. Simbol

Simbol adalah tanda yang muncul karena adanya kesepakatan bersama.

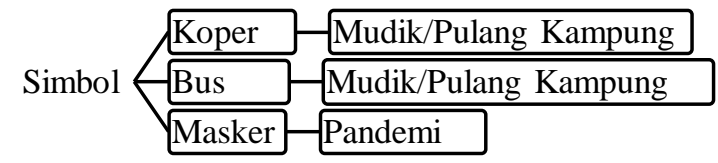

1) Koper dan Bus merupakan simbol dari pemudik. Pemudik biasanya membawa oleh-oleh dan menginap di kampung sehingga membawa koper atau barang yang banyak. Bus merupakan salah satu transportasi publik yang digunakan untuk perjalanan antar daerah.

2) Masker menunjukkan pandemi covid-19.

Kebijakan pemerintah yang tergambarkan dalam karikatur dilarang mudik tapi boleh pulang kampung ketidak konsistenan antara Presiden dan Menteri Perhubungan. Pernyataan presiden dalam Mata Najwa secara tidak langsung melonggarkan aturan yang terdapat dalam surat edaran PM no 25 Tahun 2020 tentang larangan mudik. Reaksi masyarakat yang tergambarkan juga terlihat bersikeras untuk mudik. Ada anggapan yang muncul bahwa mudik dan pulang kampung itu berbeda, yang dilarang adalah mudik, sedangkan mereka pulang kampung. Terlihat perlawanan yang muncul terhadap surat edaran PM no. 25 Tahun 2020.

\section{KESIMPULAN}

Berdasarkan hasil analisis data karikatur covid-19 yang membahas tentang kebijakan pemerintah dalam @tempodotco dan @hariankompas, maka penulis menyimpulkan sebagai berikut. Kesimpulan ini terbagi atas dua, yaitu penggambaran yang muncul tentang kebijakan pemerintah, dan penggambaran yang muncul dari reaksi masyarakat terhadap kebijakan pemerintah. 


\section{Penggambaran yang muncul tentang kebijakan pemerintah.}

1) Penetapan kebijakan pemerintah digambarkan kurang ketat terhadap pelaksanaan protokol kesehatan. Pemerintah melaksanakan aturan prokes dengan tetap mempertimbangkan masalah ekonomi atau kebijakannya yang lain. Sehingga, terjadi pelonggaran prokes untuk aturan-aturan yang berlawanan dengan kebijakan. Hal ini terlihat dari pelaksanaan pilkada, penerapan new normal atau pemeberhentian PSBB, dan pernyataan Jokowi yang membedakan antara mudik dan pulang kampung.

2) Kebijakan pemerintah yang terlaksana digambarkan mematuhi prokes namun tidak memberikan solusi untuk dampak yang muncul. Misalnya pelaksanaan WFH atau belajar dari rumah, dan PSBB. WFH membuat pekerjaan kantor menjadi tidak efisien. Pegawai yang bekerja dari rumah tidak sepenuhnya dapat fokus terhadap pekerjaan kantornya. Mereka seringkali ikut terlibat dengan pekerjaan rumah, dan tidak semua kerjaan kantor bisa dikerjakan dari rumah. Masalah jaringan dan teknologi terjadi dalam kasus belajar dari rumah. Tidak semua orang mempunyai fasilitas HP dan jaringan yang baik. Orang tua juga semakin stress karna harus mengawasi proses belajar anak di rumah. PSBB yang berlaku juga memberatkan masyarakat dengan upah harian. Tidak semua orang bekerja dengan upah bulanan atau khawatir dengan pemasukan mereka.

3) Opini yang disampaikan oleh beberapa pejabat pemerintah terkesan menyepelekan covid-19. Bahkan ada pejabat yang memberikan opini tak berdasar tentang covid-19 yang dapat merugikan masyarakat.

4) Keegoisan pejabat pemerintah digambarkan dengan pemberian bantuan sosial yang berkedok kampanye.

Penggambaran yang muncul dari reaksi masyarakat terhadap kebijakan pemerintah.

1) Masyarakat digambarkan tidak mematuhi aturan pemerintah dengan baik. Misalnya dalam pelaksanaan larangan mudik atau PSBB. Masyarakat tidak sepenuhnya dapat melaksanakan PSBB karna adanya faktor kebutuhan hidup yang tidak terpenuhi oleh pemerintah. Masyarakat juga terlihat mengambil celah terhadap kebijakan larangan mudik. Pernyataan Presiden sebelumnya menjadi celah untuk melakukan perjalanan ke daerah. Selain itu, pemerintah hanya melarang perjalanan antara regional yang berbeda.Perjalanan daerah dalam regional yang sama diperbolehkan sehingga terjadi mudik lokal.

2) Pegawai atau siswa tidak dapat melakukan tugasnya dengan efisien. Pegawai yang bekerja di rumah sering terlibat pekerjaan lain. Pembelajaran online membuat siswa menjadi semakin malas. Belajar di rumah malah dianggap sebagai liburan.

3) Manusia digambarkan sebagai burung dalam sangkar. Dengan adanya protokol kesehatan, masyarakat yang patuh sebisa mungkin untuk tetap tinggal di rumah.

\section{Daftar Pustaka}

Agustino, Leo. 2020. Analisis Kebijakan Penanganan Wabah Covid-19: Pengalaman Indonesia. Jurnal Borneo Administrator, Vol. 16 No. 2, 253-270, Agustus 2020. https://samarinda.lan.go.id/jba/index.php/jba/article/view/685. Diakses pada 8 Juni 2021.

Alfiyah, Nur. 7 Maret 2020. Dalam Pantauan Radar Covid-19. Majalah Tempo Edisi 7 Maret 2020.. https://majalah.tempo.co/read/laporan-utama/159895/cara-daerah-menanganipasien-corona. Diakses pada 20 Mei 2021

Alkhresheh, Mutaz Mohammad. 2020. Semiological Discourse Analysis of the Editorial Cartoons of International Newspapers on COVID-1. Indian Journal of Forensic Medicine \& Toxicology, October-December 2020, Vol. $14, \quad$ No. 4. 
https://medicopublication.com/index.php/ijfmt/article/view/12564/11564. Diakses pada 1 Juni 2021.

Amalia, Nafiatul. 2020. Simbolisme Fauna pada Penamaan Surah dalam Al-Qur'an: Kajian Semiotika. Tesis.

Barthes, Roland. 2011. Mitologi. Dialihbahasakan oleh Nurhadi, \& A. Sihabul Millah. Bantul Yogyakarta DIY: Kreasi Wacana.

Christomy. 2004. Semiotika Budaya. In Semiotika Budaya, by Yuwono, 117. Depok: Pusat Penelitian Kemasyarakatan dan Budaya UI.

Danang, Martinus. 8 Desember 2020. Pilkada 2020 di Tengah Pandemi Covid-19. https://kompaspedia.kompas.id/baca/infografik/kronologi/pilkada-2020-di-tengahpandemi-covid-19. diakses pada 10 Juni 2021

Diaz, R. 2012. Pemaknaan Karikatur Nunun Nurbaeti pada Cover Majalah Tempo (Studi Semiotika pemaknaan karikatur "Mafia Di Balik Nunun" Pada Cover Majalah Tempo edisi 19-25 Desember 2011) (Doctoral dissertation, UPN" veteran" Jawa Timur). diakses pada 5 Juni 2021. https://core.ac.uk/display/12218555

Dwiyanto, A., \& Wihardi, D. 2020. Analisis Semiotika Charles Sanders Pierce Pada Cover Majalah Tempo Online Edisi 25 Februari-03 Maret 2019. PANTAREI,4(03). https://jom.fikom.budiluhur.ac.id/index.php/Pantarei/article/view/579. diakses pada 3 Juni 2021.

Ernis, Devy. 14 Maret 2020. Akrobat Tanpa Kabar Pusat. Majalah Tempo Edisi 14 Maret 2020. https://majalah.tempo.co/read/laporan-utama/159951/berantakannya-koordinasipemerintah-pusat-dan-daerah-menanggulangi-corona. diakses pada 5 Maret 2021.

Gubernur Provinsi Daerah Khusus Ibukota Jakarta. 2020. Peraturan Gubernur Daerah Khusus $\begin{array}{llllr}\text { Ibukota Nakarta } & \text { Nomor } & 33 & \text { Tahun }\end{array}$ https://corona.jakarta.go.id/storage/documents/peraturan-gubernur-nomor-33-tahun-2020tentang-pelaksanaan-psbb-dalam-penanganan-covid-19-di-provinsi-dki-jakarta5e987d4687853.pdf. diakses ada 13 Juni 2021.

Hasyim, Muhammad. 2014. Konstruksi Mitos dan Ideologi dalam Teks Iklan Komersial Televisi, Suatu Analisis Semiologi. Makassar: Universitas Hasanuddin.

Hennida, Citra. 2020. Keberhasilan Penanganan COVID-19 di Singapura: Kasus Klaster Pekerja Migran dan Resesi Ekonomi. Global Strategis, Th. 14, No. 2. Universitas Airlangga. https://e-journal.unair.ac.id/JGS/article/view/21365. diakses pada 4 Maret 2021.

Hoed, Benny H. Semiotik \& Dinamika Sosial Budaya. Komunitas Bambu: Depok, 2014.

Kamus Besar Bahasa Indonesia (KBBI). 2020. https://kbbi.web.id/karikatur

—. 2020. https://kbbi.web.id/mudik. diakses pada 18 Juni 2021.

Kementrian Kesehatan. 2020. Surat Edaran Larangan Penggunaan Bilik Disinfektasi. https://covid19.kemkes.go.id/download/SE_Penggunaan_Bilik_Desinfeksi_dalam_Rangk a_Pencegahan_Penularan_Covid_19.pd. Diakses pada 25 Maret 2020.

KompasTV. 7 September 2020. Jokowi Pastikan, Pilkada Serentak 2020 Harus Tetap Dilakukan. https://www.youtube.com/watch?v=oBwh7HugPI4 diakses pada 5 Juli 2020.

- 27 Maret 2020. Keren! Surabaya Ciptakan Inovasi Bilik Disinfektan. https://www.youtube.com/watch?v=QKYxLRn6M2c. diakses pada 5 Juli 2020.

Armin, M.A., \& Amalia, N. 2020. Semiotika Karikatur Pandemi Covid-19 Melalui Media Daring (on line) di Perancis. Jurnal Ilmu Budaya 8 (2), 279-293. https://journal.unhas.ac.id/index.php/jib/article/view/11106. diakses pada 13 Maret 2020. 
Menteri Perhubungan Republik Indonesia. 2020. Peraturan Menteri Perhubungan Republik $\begin{array}{lllll}\text { Indonesia } & \text { Nomor } & \text { PM } & 25 & \text { Tahun }\end{array}$ http://jdih.dephub.go.id/assets/uudocs/permen/2020/PM_25_TAHUN_2020.pdf $\$ diakses pada 15 Juni 2020.

metrotvnews, 22 September 2020. KPU, Bawaslu, dan Paslon Positif Covid-19, Pilkada 2020 Tetap Berlanjut. https://www.youtube.com/watch?v=bdesGqxmSU4. diakses pada 15 Juli 2021.

Najwa Shihab. 23 April 2020. Jokowi Diuji Pandemi - Jokowi: Mudik dan Pulang Kampung Itu Beda (Part 2) | Mata Najwa https://www.youtube.com/watch?v=BC6F6Uxw1G0. diakses pada 7 Juni 2021.

Noth, Winfried. 1995. Handbook of Semiotics. Library of Congress Cataloging-in-Publication Data : United States of America

Nuriarta, I Wayan. 2020. Tanda dan Makna Kartun Mice pada Koran Kompas Edisi 8 Maret 2020. Jurnal Studi Budaya Nusantara. https://jsbn.ub.ac.id/index.php/sbn/article/view/74. diakses pada 7 Juni 2021.

Putra, A. M. 2020. Analisis Semiotika Gambar Ilustrasi "Jokowi Pinokio" pada Cover Majalah Tempo Edisi "Janji Tinggal Janji" (Doctoral dissertation, FISIP UNPAS). Skripsi http://repository.unpas.ac.id/49139/. diakses pada 19 Maret 2021.

Ramli., Rahman, Nurhayati., Gusnawaty. 2019. Bentuk, Makna dan Fungsi Pemali pada Perilaku Masyarakat Pesisir Kabupaten Maros: Pendekatan Semiotik. Jurnal Ilmu Budaya Volume 7 Nomor $\quad 1 \quad$ January-Juni (61-67). https://journal.unhas.ac.id/index.php/jib/article/view/5722/3658. diakses pada 21 Juli 2021 Richmond, Tom. 2011.The Mad Art Of Carricatur. Deadline Demon Publishing: Korea. https://www.pdfdrive.com/the-mad-art-of-caricature-a-serious guide-to-drawing-funnyfaces-d186812067.html

Rikang, Raymundus. 7 Maret 2020. Lobi Corona di Jenewa. Majalah Tempo Edisi 7 Maret 2020. https://majalah.tempo.co/read/laporan-utama/159896/gusar-istana-terhadap-terawan-soalcorona. diakses 9 Maret 2021.

Robingah. 2020. Pierce's Semiotics Analysis on Benny's Cartoons Related to Covid 19 Issues. Journal of Language and Literature, $8(1), \quad 1$. https://ejournal.gunadarma.ac.id/index.php/sastra/article/view/2564. diakses 5 Maret 2021.

Sarjan,S., Mulya, K.A.K., Chadijah, S. 2020. Problematika dan Teknis Peyelengaraan Pemilihan Kepala Daerah pada Masa Pandemi Covid 19. Rechtsregel Jurnal Ilmu Hukum Vol 3, No. $1 \quad$ Agustus 2020 http://openjournal.unpam.ac.id/index.php/rjih/article/view/6620/4366.diakses 19 Juli 2020.

Sobur, Alex. 2018. Analisis Teks Media (Suatu Pengantar untuk Analsis Wacana, Analisis Semiotik, dan Analisis Framing). Bandung: Remaja Rosdakarya.

—. 2017. Semiotika Komunikasi. PT Remaja Rosdakarya : Bandung.

Staake, Bob. 1991. The Complete Book of Caricature. North Light Books: Ohio.

St Victor Marulitua, L. T. 2015. Pembuktian Keberadaan Kritik Sosial pada Surat Kabar Jawa Pos Clekit. https://adoc.pub/pembuktian-keberadaan-kritik-sosial-dalam-karikatur-padasur.html.diakses 8 Maret 2020.

Sugiyono. 2017. Metode Penelitian Pendidikan. Alfa Beta: Bandung. 
Supriadi, S., Maknun, T., \& Said, I. M. 2019. Karikatur Politik dalam Media Cetak Harian Rakyat Sulsel: Kajian Semiotik. Jurnal Ilmu Budaya, 7(1), 134-145. https://journal.unhas.ac.id/index.php/jib/article/view/6436 diakses pada 5 Maret 2021.

Surya Citra Televisi (SCTV). 31 Mar 2020. Sejumlah Tempat Publik Sediakan Bilik Disinfektan untuk Cegah Corona, Amankah. https://www.youtube.com/watch?v=DhN216eU21M. diakses pada 5 Juni 2021.

Suryono, Joko. Dkk. 2019. Karikatur Iklan Politik Media Luar Ruang Jangan Membeli Kucing dalam Karung. Sukoharjo: Universitas Veteran Bandung Nusantara. http://ejournal.uinsuka.ac.id/isoshum/profetik/article/view/1539/1314. diakses pada 3 Maret 2020.

Titiyoga, Gabriel Wahyu. 7 Maret 2020. Panjang Nalar Melawan Sampar. Majalah Tempo Edisi 7 Maret 2020. https://majalah.tempo.co/read/laporan-utama/159880/mengapa-wabahcorona-menyebar-pesat-di-korea-iran-dan-italia. diakses pada 5 Maret 2020.

World Health Organization. 2020. WHO Emergency Dashboard. https://covid19.who.int/region/wpro/country/sg. diakses pada 9 Juni 2021.

Waluyanto, Heru Dwi. 2000. Karikatur Sebagai Karya Komunikasi Visual dalam Penyampaian Kritik Sosial. Nirmana, 2(2), 128-134. http://nirmana.petra.ac.id/index.php/dkv/article/view/16059. diakses pada 9 Maret 2021.

Zoest, Aart van. 1993. SEMIOTIKA Tentang Tanda, Cara Kerjanya dan Apa yang Kita Lakukan Dengannya. Dialihbahasakan oleh Ani Soekowati. Yayasan Sumber Agung: Jakarta. 